\title{
Evaluation by a Finite Element Method of the Flexibility Factor and Fixity Degree for the Base Plate Connections Commonly Used
}

\author{
M. Hamizi and N. E. Hannachi
}

Université Mouloud Mammeri, Département de Génie Civil, Tizi-Ouzou, Algérie

УЛК 539.4

\section{Оценка методом конечных элементов коэффициента гибкости и степени устойчивости типичных узлов соединения опорных пластин с основанием}

\section{М. Хамизи, Н. Э. Ханнаши}

Университет им. Мулуда Маммери, отделение гражданского строительства, ТизиУзу, Алжир

С использованием конечноэлементного подхода определень значения коэффициента гибкости и степени устойчивости узлов соединения стальной балки с железобетонныл основанием. Исследуются два типа соединений: в первом стальная опорная пластина с приваренной к ней вертикальной балкой крепится к железобетонному основанию двумя анкерныли болтами, которые расположень на оси симметрии двутавровой балки, во втором четьрьмя болтами. Задавались два типа нагружения: первое соединение подвергалось действию перерезывающей силь и изгибающего момента, второе - перерезывающей силь, изгибаюшего момента и осевой силь сжатия. Для описания реального поведения этих соединений использовался подход, учитьвваючий условия контакта и трения между опорной балкой и железобетонным основанием. Подход основан на односторонней зависимости для контактной задачи с кулоновским трением. Для повышения точности численных расчетов используется модифицированньий метод Лагранжа. Получень диагралиь в координатах момент-угловое перемещение и коэффиииент гибкости-расстояние от вериины вертикальной балки до опорной плить. Определено влияние степени устойчивости соединений на допустимые нагрузки и деформации.

Ключевые слова: соединения колонн и оснований, коэффициент гибкости, степень устойчивости, конечноэлементный подход, односторонний контакт, кривые момент-угловое перемещение.

Introduction. Today, to study the steel connections between a steel column and a reinforced concrete foundation as a perfectly pinned connection $(R=0)$ or fully rigid connection $(R=\infty)$ is not quite realistic approach. Numerous and well-documented studies in the past few decades have shown the nonlinear behavior of the connections and their nonperfect rigidity or flexibility. The factor of rigidity $R$ expressed in $\mathrm{kN} \cdot \mathrm{m} / \mathrm{rad}$ covers the whole range of the values varying from zero to $\infty$. The tools of design as well as the standards used in the computer codes do not take into account this partial rigidity of the connections. Assuming an idealized behavior for column base connections (perfectly pinned or fully rigid) does not reflect the true behavior of these connections and even less 
the consequences for the results of analyses, mainly the internal force distribution between members and structural deformations. The partial flexibility $(\lambda=1 / R)$ of column bases and its consequences, like a fixity degree $\gamma$, on the analysis of steel structures have drawn less attention from research community than beam-tocolumn connections. Nevertheless, results from all studies tend to confirm that column base connections exhibit semi-rigid behavior. Galambos [1] was the first to demonstrate the effect of column base fixity on strength of column. He concluded that the buckling strength of rigid frames could benefit positively from the partial rigidity of column base connections. Two decades later, Nixon [2] picked up the Galambos theoretical equations and demonstrated that the increased strength of column could lead to non-negligible savings in light industrial buildings. In 1970, an experimental research was undertaken at Laval University of Quebec (Canada). The results obtained by Lizotte and Beaulieu [3] showed that the degree of base plate fixity of a simple two-anchor-bolt column base, nominally assumed to be pinned, was such that it could be considered as a fixed base connection until buckling occurred. Also, the moment developed at the base before buckling did not induce rotation of the base plate. Later, Picard and Dion [4], Samson and Beaulieu [5], and Perruse and Beaulieu [6], showed that the presence of axial load significantly increases the degree of column base fixity, and if considered in column analysis, it reduces the effective length of the column, reduces second order $(P-\Delta)$ effects, and leads to more realistic bending moment distribution in the column. The base restraint coefficient $\left(G_{L}\right)$ then recommended by Canadian Standard S16 (CSA 1978 and CSA 2001) [7, 8] for assumed pinned or fixed column base connection appeared conservative and was consequently not appropriate. Also Eurocode 3 [9] treats these connections either as pinned or fixed. Knowing the true degree of fixity, Nixon's equations led to more accurate evaluations of column buckling loads. A few years later, Beaulieu and Picard [10] showed from the results of the experimental program that column buckling seems to occur in the elastic behavior zone of the column-foundation connection, that is, the linear portion at the beginning of the $M-\theta$ curve. Also, they showed that the number of anchors and their size do not influence the buckling resistance, but they believed that eventually substantial material economy could be gained if the true rigidity of column base connections was taken into consideration; for instance, in the design of industrial structures. Experimental research by Melchers [11] also demonstrated the moment resistance capacity of assumed pinned column base connections and identified parameters that influence column base rigidity, such as base plate thickness; anchor bolt size and column size. These results were confirmed by Pensirini and Colson [12]. They show that the initial stiffness and ultimate capacity of the connection are significantly dependent on the column axial load. In 1996, Ermopoulos and Stamatopoulos [13] reached the conclusion that increased axial loading confers higher rigidity to column base connection. They identified parameters that influence column base rigidity, such as a base plate thickness, anchor bolt size, the concrete stress, the nonlinear contact between base plate and concrete foundation. One year later, the same authors [14] proposed an analytical modeling of column base plates under cyclic loading based on mathematical model. Following these results, another study undertaken by Kootolen and Baniotopoulos [15] showed the effect of axial 
load on the displacements of base plate. They simulated the nonlinear contact between base plate and concrete foundation. The last study has been carried out by Dumas, Beaulieu, and Picard [16]. Results obtained from finite element model show that consideration of the semi-rigidity of column base connections increases the accuracy of the analysis results and leads to a decrease in structure weight and deformation.

1. Development of the Model by Finite Element. Taking into account studies enumerated above and the various recommendations made by the authors, we built a two-dimension finite element model based on the nonlinear analysis of the structure to simulate the behavior of column base plate connection. The model takes into account the nonlinearity of materials and the nonlinearity of contact between the foundation and the base plate, where it simulates the rising of the base plate and where friction at the interface concrete foundation-base plate is ensured by four nodes quadratic elements [17]. The model is established in CASTEM3M computer code.

1.1. Unilateral Contact (the Signorini Problem). In numerous simulations, the law of unilateral contact used is illustrated by the problem of Signorini. Let us consider a deformable body in contact with a rigid body (Fig. 1), the conditions of unilateral contact of Signorini having to be respected in all points of the deformable bodies located in the contact $\Gamma_{C}$ are [18]:

$$
\begin{gathered}
h \leq 0, \\
R_{\vec{n}} \leq 0, \\
h \cdot R_{\vec{n}}=0,
\end{gathered}
$$

where $h$ is the interstice or the displacement of a point of contact in the normal direction to the contact $\vec{n}$, and $R_{\vec{n}}$ is the component of the normal effort. Equation (1a) translates the condition of impenetrability, equation (1b) - the fact that the normal force of contact is compression, and equation (1c) represents the condition of complementarily (if the point is in contact then $h=0$ and $R_{\vec{n}} \leq 0$, if the point leaves the contact then $h<0$ and $R_{\bar{n}}=0$ ) [18].

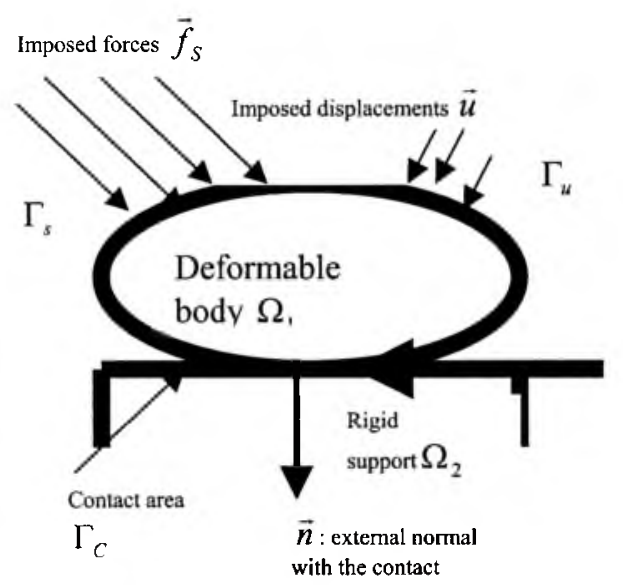

Fig. 1. Contact between a deformable body and rigid body (the Signorini problem). 
1.2. Coulomb's Law. The force at the point of contact can be broken up into a normal force $R_{\vec{n}}$ and a tangential force $R_{\vec{t}}\left(\vec{R}=R_{\vec{n}} \cdot \vec{n}+R_{\vec{t}} \cdot \vec{t}\right)$. The model of Coulomb is written in the following way [18]:

$$
\begin{gathered}
\left|R_{\vec{t}}\right| \leq \mu\left|R_{\vec{n}}\right|, \\
\left|R_{\vec{t}}\right|<\mu\left|R_{\bar{n}}\right| \Rightarrow v_{\bar{t}}=0 \quad \text { (adherence), } \\
R_{\bar{t}}=-\mu\left|R_{\bar{n}}\right| \frac{v_{\vec{t}}}{\left|v_{\bar{t}}\right|} \quad \text { (slip), }
\end{gathered}
$$

where $v_{\bar{f}}$ is the tangential relative speed between the two bodies and $\mu$ is the friction coefficient of Coulomb (Fig. 2) which includes all the local parameters, such as roughness between the two bodies.

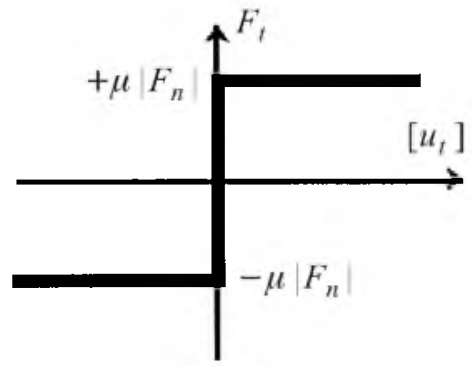

Fig. 2. The Coulomb law.

1.3. Equilibrium without Friction. A deformable body $\Omega_{1}$ and a rigid body $\Omega_{2}$ are considered, we note by $\Omega=\Omega_{1} \cup \Omega_{2}$ the total of the two bodies. The deformable body is subjected to the imposed displacements $\vec{u}_{d}$ on the zone $\Gamma_{u}$, to applied loads $\vec{f}_{S}$ on the zone $\Gamma_{\sigma}$, and to forces of volumes $\vec{f}_{V}$ acting on the field (Fig. 1)

$$
\begin{gathered}
\operatorname{div} \vec{\sigma}+\vec{f}_{V}=0 \quad \text { in } \quad \Omega, \\
\vec{u}=\vec{u}_{d} \quad \text { on } \quad \Gamma_{u}, \\
{[\sigma] \cdot \vec{n}=\vec{f}_{S} \text { on } \quad \Gamma_{\sigma},} \\
{[\sigma] \cdot \vec{n}=\vec{R} \quad \text { on } \quad \Gamma_{C} .}
\end{gathered}
$$

1.4. Equilibrium with Friction. Equilibrium of deformable body $\Omega_{1}$ with frictional contact is described by

$$
W_{\text {bodv }}=\frac{1}{2} \int_{V}[\sigma]\{\varepsilon\} d V-\int_{V} \vec{f}_{V} \cdot \vec{u} d V-\int_{\Gamma_{C}} \vec{f}_{V} \cdot \vec{u} d S-W_{\text {cont }} .
$$


The work of the actions of contact on the deformable body is written as

$$
W_{\text {cont }}=\iint_{\Gamma_{C}}\left(R_{n} \vec{n} \cdot \vec{u}_{n}+\vec{R}_{t} \cdot \vec{u}_{t}\right) d S
$$

with

$$
\vec{u}_{t}=\left(\vec{u}_{2}-\vec{u}_{1}\right)-\vec{u}_{n} \cdot \vec{n}
$$

The actions of rigid body $\Omega_{2}$ on body $\Omega_{1}$ are described by

$$
\vec{f}_{\text {cont }}=\iint_{\Gamma_{C}}\left(R_{n} \cdot \vec{n}+\vec{R}_{t}\right) d S .
$$

1.5. Finite Element Modeling.

$$
\begin{gathered}
\sigma=C / \varepsilon \quad \text { (behavior law), } \\
\varepsilon=[B] u \quad \text { (interpolation of deformations), } \\
u=[N] u^{k} \quad \text { (interpolation of displacements). }
\end{gathered}
$$

In matrix form the Eq. (7) is written

$$
W_{\text {body }}=\frac{1}{2} u^{T}[K] u-u^{T}\{F\}
$$

with rigidity matrix

$$
[K]=\int_{V} B^{T}[C] B d V,
$$

and vector of the external efforts

$$
\{F\}=\int_{V}\left[N^{T}\right] \vec{f}_{V} d V+\int_{\Gamma_{C}}\left[N^{T}\right] \vec{f}_{S} d S+\int_{\Gamma_{C}}\left[N^{T}\right] \vec{f}_{c o n t} d S .
$$

The equilibrium of the system with frictional contact amounts to minimize the energy equation under the following constraint:

$$
\left\{\begin{array}{l}
\operatorname{div} \sigma \equiv \delta W_{\text {body }}=0, \\
h=\left(\left(\vec{u}_{2}-\vec{u}_{1}\right) \cdot \vec{n}\right) \cdot \vec{n}=[G]^{T} u_{n}=0 .
\end{array}\right.
$$

1.6. Method of Resolution (Augmented Lagrangian Problem). The method of resolution is based on combination of the penalization and Lagrangian methods. We have to insert a large term $\alpha$ (penalization coefficient) and $\lambda$ (Lagrangian multiplier) into the energy equation (10) [19]: 


$$
\begin{gathered}
W_{\text {body }}(u, \lambda)=\frac{1}{2} u^{T}[K] u+\lambda^{T}[G]^{T} u+\frac{\alpha}{2} u^{T}[G][G]^{T} u=0, \\
\delta W_{\text {body }}(u, \lambda)=0 \Rightarrow\left\{\begin{array} { l } 
{ \frac { \partial W } { \partial u } = 0 , } \\
{ \frac { \partial W } { \partial \lambda } = 0 , }
\end{array} \Rightarrow \left\{\begin{array}{l}
{\left[K+\alpha G G^{T}\right] u^{K}+[G] \lambda^{k}=F,} \\
\lambda^{K+1}=\lambda^{K}+\alpha[G]^{T} u^{K} .
\end{array}\right.\right.
\end{gathered}
$$

2. Behavior Laws. For the finite elements model, we adopted for the column and the base plate, and anchors bolts the behavior laws illustrated by Figs. 3 and 4, respectively.
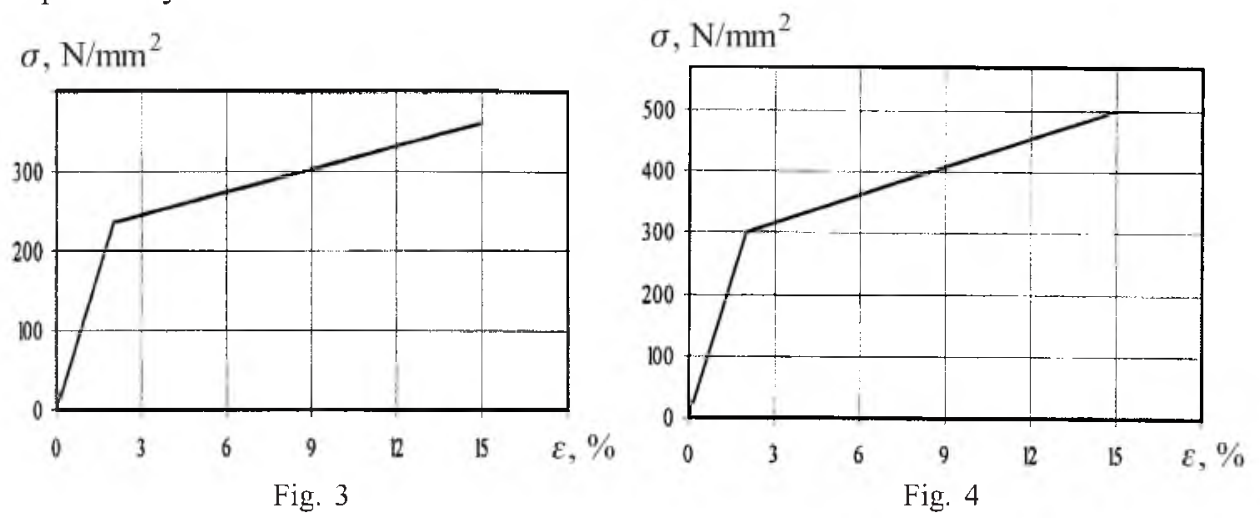

Fig. 3. Adopted stress-strain relations for the steel column and base plate connection. Fig. 4. Adopted stress-strain relations for the anchor bolts.

For the foundation concrete, the material is considered to operate in the elastoplastic field with the Young modulus $E_{C}=29 \mathrm{GPa}$, Poisson ratio $\gamma_{C}=0.18$, tensile strength $f_{t}=3 \mathrm{MPa}$, and compressive strength $f_{c}=38 \mathrm{MPa}$.

3. Numerical Examples. In this study, two types of connections are analyzed. The first one consists of a base plate welded to the end of column and attached to the reinforced concrete foundation with two anchor bolts. These bolts are placed on the major axis of the I-shaped column cross section, one anchor bolt on each side of the web (Fig. 5). In the second configuration, the connection comprises a base plate and four anchor bolts placed outside the flanges of the I-shaped section (Fig. 6). Two loading types are used. First, the connections were subjected to shear force and a bending moment only, then the connections were put under shear force, a bending moment and an axial compressive force (Fig. 7). In this case a bending moment is caused by the offset compressive load. Different eccentricities and variable axial loadings $(P=100$ to $600 \mathrm{kN})$ are chosen, in order to show the influence of these parameters of the degree of fixity of the column base connections.

The following measures have been in order to perform correctly this study:

- An interaction between the holes in the base plate and the anchor bolts is ensured by considering a unilateral contact between these two bodies.

- In order to simplify the mesh, the anchor bolts that are of circular sections are simulated in this study by bolts of square sections of equivalent surface. 
Evaluation by a Finite Element Method...

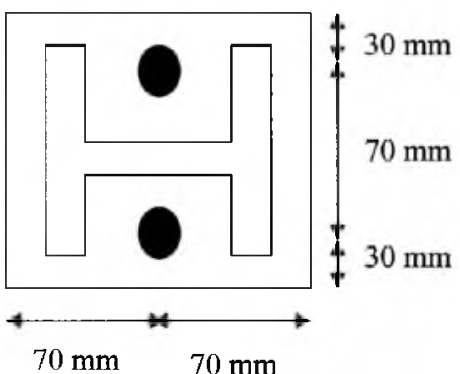

Fig. 5

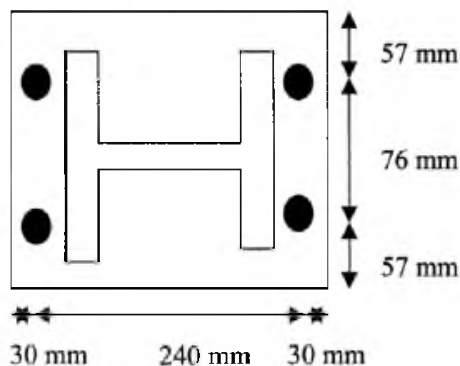

Fig. 6

Fig. 5. Detail of two anchors bolts connection FT (HE100 B: $A=26 \cdot 10^{2} \mathrm{~mm}^{2}, I_{x}=449.5 \cdot 10^{3}$ $\left.\mathrm{mm}^{4}, S_{x}=89.91 \cdot 10^{3} \mathrm{~mm}^{3}, h=100 \mathrm{~mm}, b=100 \mathrm{~mm}, t_{f}=10 \mathrm{~mm}, t_{w}=6 \mathrm{~mm}\right)$.

Fig. 6. Detail of four anchor bolts' connection CFT (HE160 B: $A=54.3 \cdot 10^{2} \mathrm{~mm}^{2}, I_{x}=$ $\left.=2492 \cdot 10^{3} \mathrm{~mm}^{4}, S_{x}=311.5 \cdot 10^{3} \mathrm{~mm}^{3}, h=160 \mathrm{~mm}, b=160 \mathrm{~mm}, t_{f}=13 \mathrm{~mm}, t_{w}=8 \mathrm{~mm}\right)$.

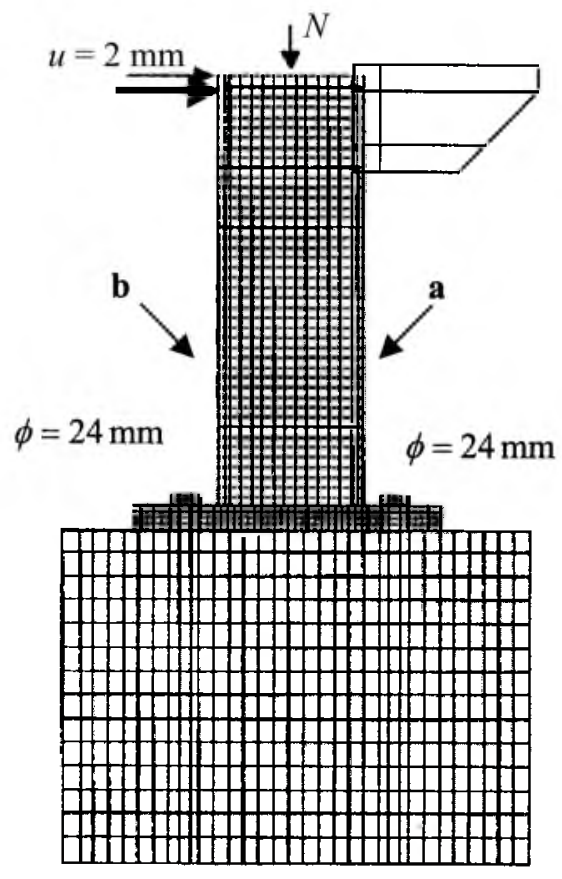

Fig. 7. Finite element mesh of the 3D model

- The simulation of the anchor bolts is made so that the nodes coincide with the nodes of the holes of the base plate.

- To take into account the problem of contact friction between the base plate and the foundation, the nodes as well as the degrees of freedom of the two bodies are selected so that they coincide.

- The same precaution is also taken with regard to the nodes and the degrees of freedom of the anchor bolts and the concrete foundation.

- Traction in the concrete develops only in the higher part of bolt (on the third of $L_{P}$ ). 
- The loadings are introduced in the forms of increments (ensured by CASTEM3M code).

- Precautions are also taken with regard to the measurement of rotations in levels which coincide with the experimental study [4] and this rotation $\theta=$ $=(a-b) / x$ in which $a$ and $b$ are the displacement measured on the flanges of the column at the imposed distances $x$ [16] (Fig. 7).

- The deformation of the soil under the concrete foundation is neglected owing to the fact that the bending moment developed at the column base plate seems weak to force the foundation.

- The results of our model were compared with the experimental results obtained in [4].

The details of connections are shown in Table 1 .

$\mathrm{T}$ a b 1 e 1

Studied Parameters Values

\begin{tabular}{|l|c|c|c|c|c|c|c|c|c|}
\hline \multicolumn{1}{|c|}{ Connection } & FT1 & FT4 & CFT1 & CFT3 & CFT6 & CFT6 & CFT6 & CFT6 & CFT6 \\
\hline Column length $L, \mathrm{~mm}$ & 1220 & 1220 & 1220 & 1220 & 1220 & 1220 & 1220 & 1220 & 1220 \\
\hline Eccentricity $e, \mathrm{~mm}$ & & & 150 & 300 & 300 & 300 & 300 & 300 & 300 \\
\hline Axial load $P, \mathrm{kN}$ & & & 300 & 200 & 100 & 200 & 300 & 400 & 600 \\
\hline $\begin{array}{l}\text { Distance } x \text { with the top } \\
\text { of the base plate (mm) }\end{array}$ & 0 & 0 & 0 & 0 & 0 & 0 & 0 & 0 & 0 \\
& 170 & 170 & 170 & 170 & 170 & 170 & 170 & 170 & 170 \\
& 350 & 350 & 350 & 350 & 350 & 350 & 350 & 350 & 350 \\
& & 430 & 430 & 430 & 430 & 430 & 430 & 430 & 430 \\
\hline
\end{tabular}

4. Results. The following moment-rotation curves were obtained (Figs. 8-12).

4.1. Moment-Rotation Curves and Comparison with Laval University Curves.

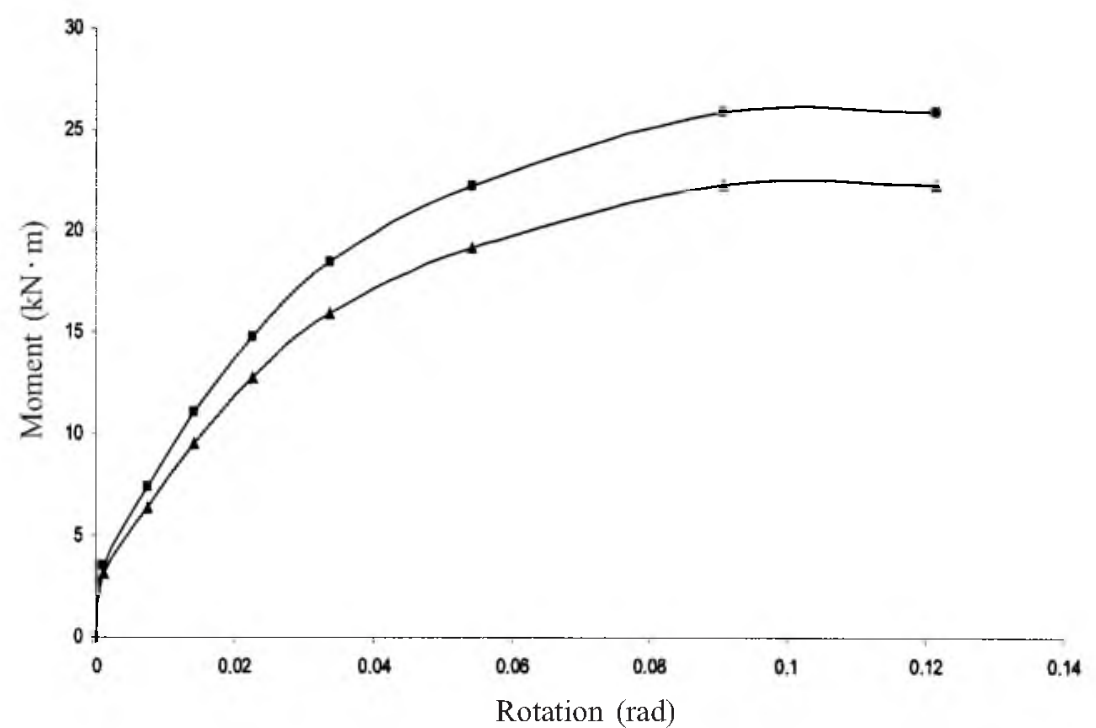

Fig. 8. Moment-rotation curve connection HE100 B with 2 anchors ("Level 1", axial load $P=0$ ): (A) FT1 experimental; (ロ) FT1 model. 


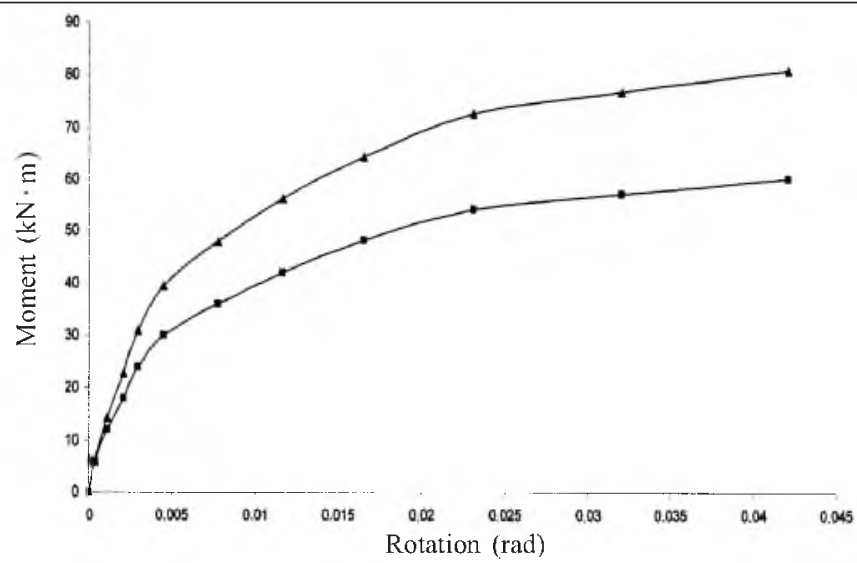

Fig. 9. Moment-rotation curve connection HE160 B with 4 anchors ("Level 1", $P=0$ ): (ם) FT4 experimental; (A) FT4 model.

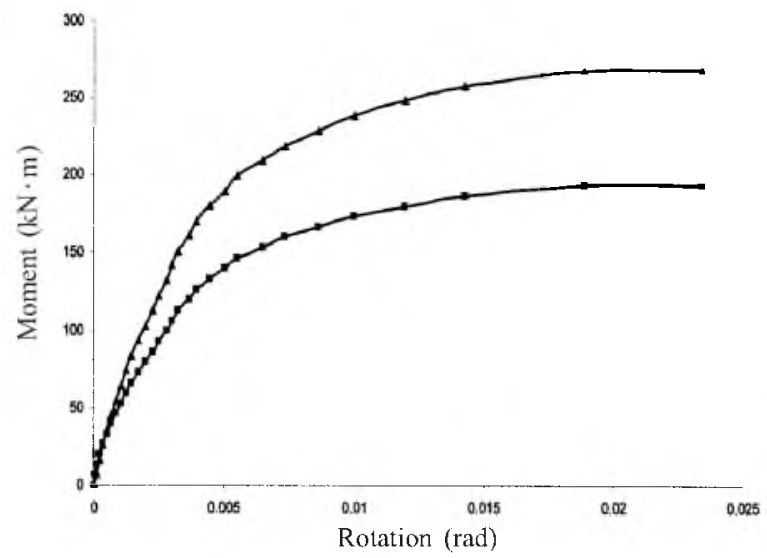

Fig. 10. Moment-rotation curve connection HE160 B with 4 anchors ("Level 1", $P=600 \mathrm{kN}$ ): (ם) CFT6 experimental; (A) CFT6 model.

\subsection{Moment-Rotation Curves of Other Connections.}

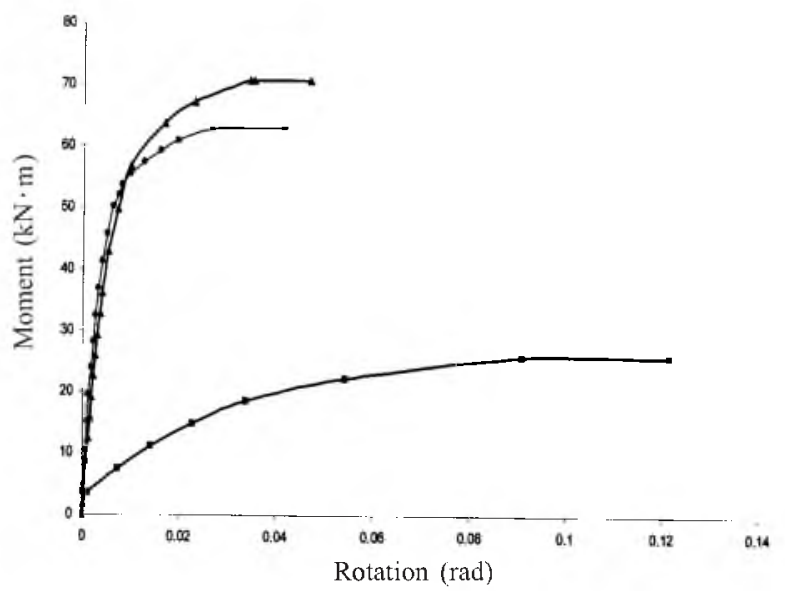

Fig. 11. Moment-rotation curve HE100 B with 2 anchors under various axial loadings: (ם) FT1, $P=0 ;(\Delta)$ CFT3, $P=200 \mathrm{kN} ;(\bullet)$ CFT1, $P=300 \mathrm{kN}$. 


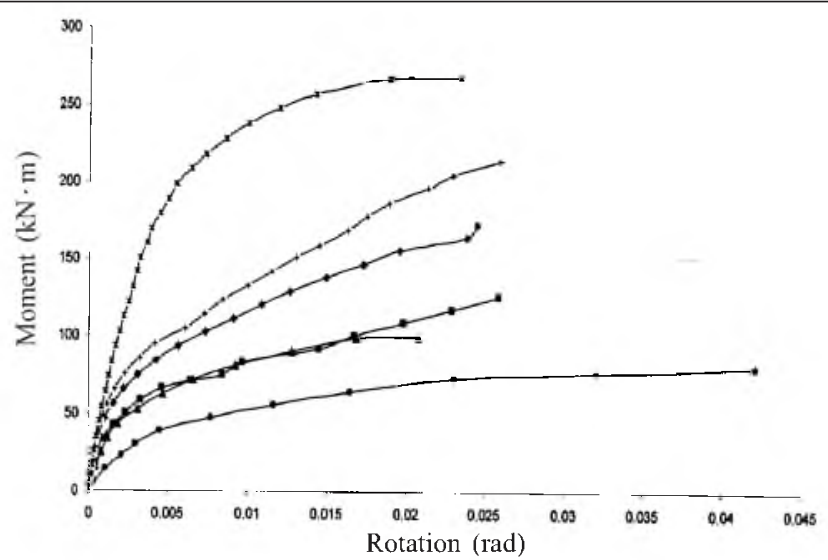

Fig. 12. Moment -rotation curve connection HE160 B with 4 anchors (FT4) for various axial load: (๑) $P=0 ;(\boldsymbol{\Delta}) P=100 \mathrm{kN} ;(\boldsymbol{\square}) P=200 \mathrm{kN} ;(\bullet) P=300 \mathrm{kN} ;(+) P=400 \mathrm{kN} ;(\times) P=600 \mathrm{kN}$.

4.3. Flexibility Factor Curves were obtained (Figs. 13-15).

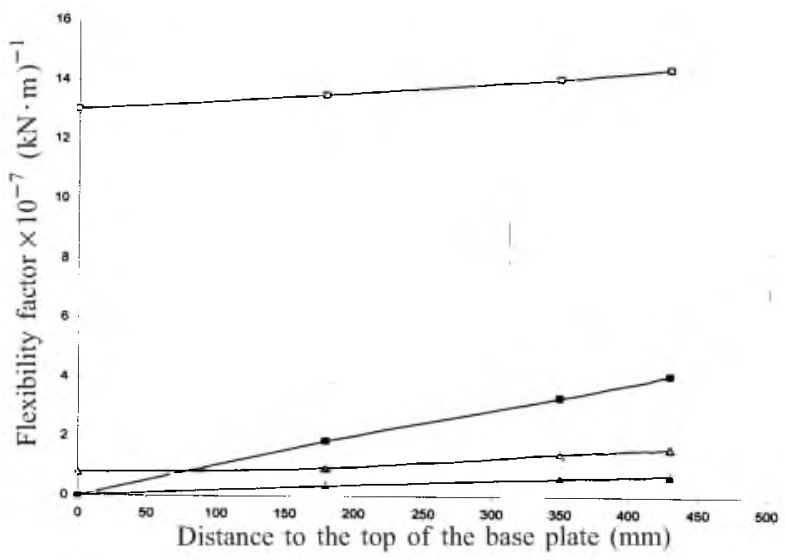

Fig. 13. Flexibility factor curves of FT1 and FT4 connections according to the distance to the top of the base plate: $(\boldsymbol{\square}),(\mathbf{\Delta})$ theoretical curves of FT1 and FT4, respectively; $(\square),(\triangle)$ model curves of FT1 and FT4, respectively.

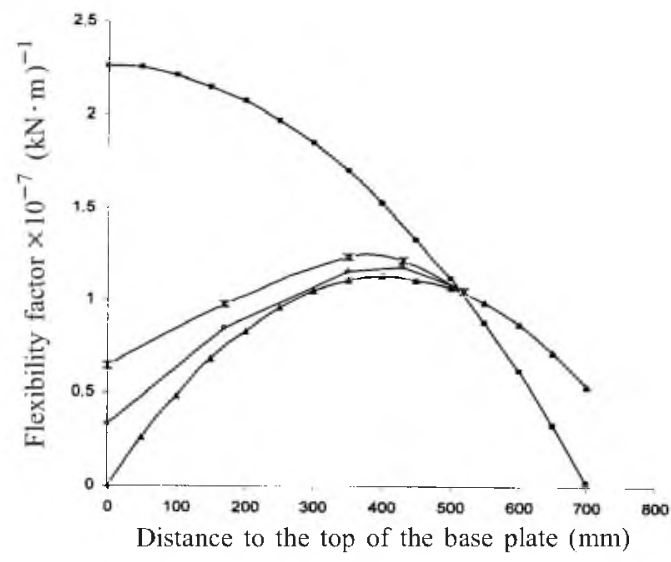

Fig. 14. Flexibility factor curves of CFT1 and CFT3 connections according to the distance to the top of the base plate: $(\boldsymbol{\square})$ theoretical curve of pinned column; $(\mathbf{\Delta})$ theoretical curve of fixed column; (*) CFT1 model; (O) CFT3 model. 


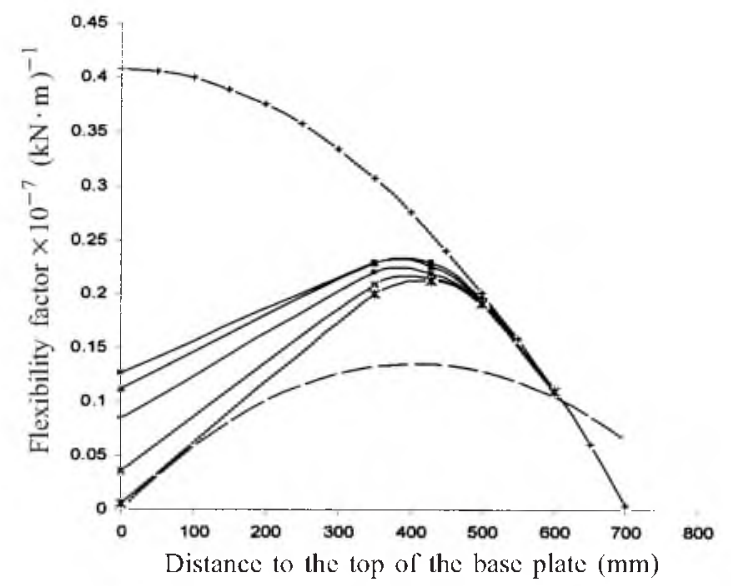

Fig. 15. Flexibility factor curves of CFT6 connection according to the distance to the top of the base plate for various axial load: $(+)$ theoretical curve of pinned column; ( $\mathbf{C})$ CFT6 model, $P=100 \mathrm{kN}$;

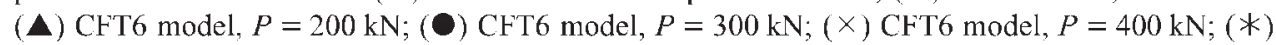
CFT6 model, $P=600 \mathrm{kN}$; dashed line corresponds theoretical curve of fixed column.

4.4. Calculation of the Fixity Degree. Once flexibility factor is calculated, we carricd out the fixity degree of the various connections. For FT connections subjected only to shear force and bending moment, their fixity degrees are calculated by using the Eq. (14) suggested by Brun and Picard [18] and we obtained the results of Table 2 ,

$$
\gamma=\frac{1}{1+\frac{3 E I \lambda_{0}}{L}} .
$$

For the CFT connections subjected to the axial load in addition to shear force and bending moment, the fixity degrees are calculated by using the linear portion of the moment-rotation curve obtained by the model. For each position of the column where rotations are evaluated, a factor is calculated by the Eq. (15) and the fixity degree of connection is given by the Eq. (16) [4]:

$$
\psi=\frac{\lambda_{\bmod x}-\lambda_{f x}}{\lambda_{r x}-\lambda_{f x}}
$$

with

$$
\lambda_{f x}=\frac{2 x L-3 x^{2}}{4 E I L} \quad \text { (fixed connection) }
$$

and

$$
\begin{gathered}
\lambda_{r x}=\frac{L^{2}-3 x^{2}}{6 E I L} \quad \text { (pinned connection), } \\
\gamma=1-\psi .
\end{gathered}
$$


$\mathrm{T}$ a b l e 2

Fixity Degrees of the FT Connections

\begin{tabular}{|c|cc|}
\hline Connection & $\lambda_{0},(\mathrm{kN} \cdot \mathrm{mm})^{-1}$ & $\gamma$ \\
FT1 & $13 \cdot 10^{-7}$ & 0.258 \\
\hline FT4 & $0.8 \cdot 10^{-7}$ & 0.505 \\
\hline
\end{tabular}

T a b l e 3

The Fixity Degrees of CFT Connections

\begin{tabular}{|c|c|c|c|c|c|c|c|}
\hline Connections & FT 1 & CFT3 & $\begin{array}{c}\text { CFT6, } \\
P=100 \mathrm{kN}\end{array}$ & $\begin{array}{c}\text { CFT6, } \\
P=200 \mathrm{kN}\end{array}$ & $\begin{array}{c}\text { CFT6, } \\
P=300 \mathrm{kN}\end{array}$ & $\begin{array}{c}\text { CFT6, } \\
P=400 \mathrm{kN}\end{array}$ & $\begin{array}{c}\text { CFT6, } \\
P=600 \mathrm{kN}\end{array}$ \\
\hline Fixity de & 0.715 & 0.855 & 0.690 & 0.710 & 0.790 & 0.910 & 0.990 \\
\hline
\end{tabular}

For CFT1, CFT3 and CFT6 connections, the values of fixity degree are summarized in Table 3.

4.5. Influence of the Fixity Degree on the Efforts and Deformations. To illustrate the influence of the rigidity of column base connection in structure analysis, a study on a simple frame (Fig. 16) subjected to axial loads $P=350 \mathrm{kN}$ and lateral load $F=44.5 \mathrm{kN}$ is carried out by considering different cases of fixity degree $(\gamma=0,0.5$, and 0.7 , and $\lambda=1)$.

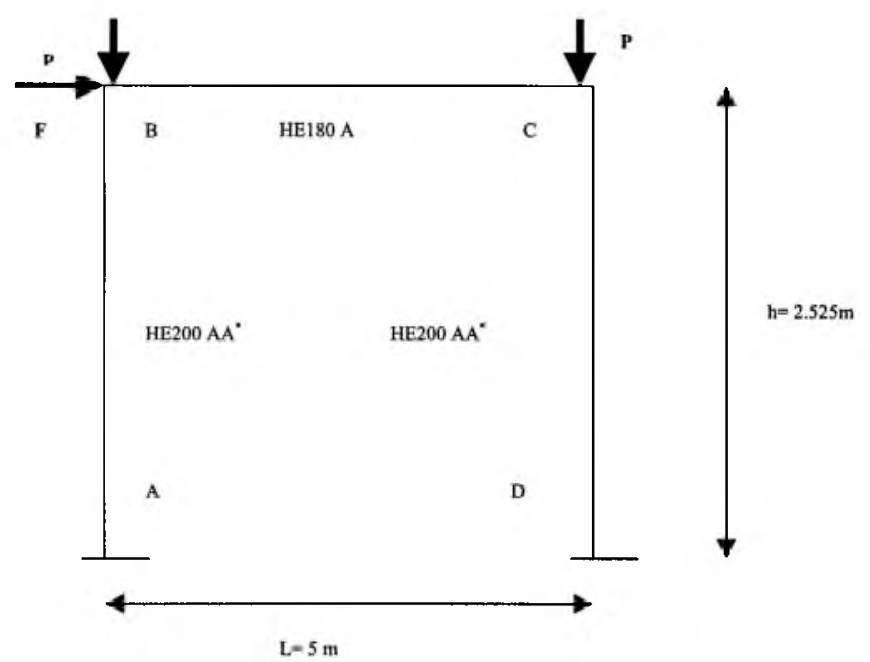

Fig. 16. Frame used to cvaluate the efforts and displacements for various fixity degrees $[(A, D)$ joints with variable rigidity; $(B, C)$ joints with fixed rigidity; $E=2 \cdot 10^{5} \mathrm{MPa}$.

The analysis of the frame has been carried out using a matrix method of structural analysis with pure linear deformation joints [20]. This method consists in modifying the rigidity matrix of the frame elements to take into account the joint rigidity using a fixity degree, which can vary from 0 to 1 . The $(P-\Delta)$ effects are included in calculations. The bending moments and lateral displacements obtained of first order analysis are multiplied by a factor of amplification $U_{0}$ [4] 


$$
U_{0}=\frac{1}{1-\frac{\sum_{i=1}^{n} P_{i} \Delta_{i}}{F h}},
$$

where $F$ is the lateral load, $P_{i}$ the axial load in the column, $\Delta_{i}$ the lateral displacement of the column, and $h$ the height of column.

Table 4 gives the moments as well as the side displacement at the head and the base of column for each degree of fixity.

$\mathrm{T}$ a b 1 e 4

Efforts and Deformations in the Column for the Various Degrees of Fixity

\begin{tabular}{|c|c|c|c|c|}
\hline Fixity degree & $\begin{array}{c}\text { Case 1 } \\
\gamma=0\end{array}$ & $\begin{array}{c}\text { Case 2 } \\
\gamma=0.5\end{array}$ & $\begin{array}{c}\text { Case 3 } \\
\gamma=0.7\end{array}$ & $\begin{array}{c}\text { Case 4 } \\
\gamma=1\end{array}$ \\
\hline $\begin{array}{c}\text { Moment at the head } \\
\text { of column }(\mathrm{kN} \cdot \mathrm{m})\end{array}$ & 56.20 & 32.9 & 28.0 & 24.6 \\
\hline $\begin{array}{c}\text { Moment at the base } \\
\text { of column }(\mathrm{kN} \cdot \mathrm{m})\end{array}$ & 0 & 28.1 & 31.9 & 34.3 \\
\hline $\begin{array}{c}\text { Side displacement } \\
\text { of the column }(\mathrm{mm})\end{array}$ & 31.15 & 12.2 & 9.6 & 6.7 \\
\hline
\end{tabular}

4.6. Comparison of the Results. We compared the results obtained for various fixity degrees used in the study (Table 5).

$\mathrm{T}$ a b 1 e 5

Comparison of the Moments and Displacements at the Head of Column According to the Degrees of Fixity

\begin{tabular}{|c|c|c|c|}
\hline & Case 1/Case 2 & Case 1/Case 3 & Case 1/Case 4 \\
\hline $\begin{array}{c}\text { Reduction of the moment } \\
\text { at the head of column }\end{array}$ & $40 \%$ & $50 \%$ & $56 \%$ \\
\hline $\begin{array}{c}\text { Reduction of the side } \\
\text { displacement }\end{array}$ & $60 \%$ & $69 \%$ & $78 \%$ \\
\hline
\end{tabular}

Conclusions. The model gives good results; the various comparisons reflect it well (see Figs. 8-10).

The assumptions that we adopted are not far from reality; the results obtained by the model fit well with the experimental results for the first steps of loadings and then under the estimated rotations. That is certainly with the fact that in reality the rotation of the foundation is not negligible. The results obtained are the following:

(i) for the connections with two anchors bolts without axial load, the model sticks very well the experimentation for $\theta<0.01 \mathrm{rad}$, after the model gives rotations lower by $10 \%$ of the experimental ones (Fig. 8); 
(ii) for the connections with four anchors bolts without axial load, the model stick very well with the experiment for $\theta<0.001 \mathrm{rad}$, after the model gives rotations lower by $20 \%$ of those of the experiment (Fig. 9);

(iii) for the connections with four anchors bolts with axial load, the model stick very well with the experiment for $\theta<0.005 \mathrm{rad}$, after the model gives rotations lower by $25 \%$ of those of the experiment (Fig. 10).

According to these results, presence of more anchor bolts in the connection prevents rotations of the column base plate to foundation. On the other hand, presence of axial load on the level of connection does not eliminate the rotation of the foundation to soil as reported in [3]. Even without axial load applied to the column, the connections FT1 and FT4 have a flexional rigidity (quite significant resistance to rotation to be considered in calculations). The connections with four anchor bolts have a higher rigidity than the connections with two anchor bolts. Presence of axial load on the top of column produces a significant increase in fixity degree of the connections compared to that obtained when no axial load is applied. If we take into account the rigidity of the column base connections as a beam-column behavior; the principal advantages are: effective reduction length of the column, reduction of the moment at the head of column, increase in the moment at the base of column, reduction of side displacement at the head of column, and reduction of the second order $(P-\Delta)$ effects.

If the minimum of fixity degree of the studied connections is equal to 0.5 in the presence of an axial load of compression, real displacement will be equal only to $40 \%$ of the displacement taken in calculations. We also see that the columns bear only about $60 \%$ of their capacity. The decrease is due not only to the $(P-\Delta)$ effects, but also because the column operaty in double curve and that maximum bending moment in the column decreases when a moment is developed in the joint at the base of columns column. We propose to take the fixity degree of column base connections equal to $0.5(\gamma=0.5)$ in calculation of steel frames, since beyond this value, the reduction of the moments and displacements at the head of column is of less importance. If the rigidity of the joint at the base of the column is considered, one can make the choice of a more economic section for the columns.

\section{Резюме}

Із використанням скінченноелементного підходу визначено значення коефіцієнта гнучкості та степеня стійкості вузлів з'єднання стальної балки із залізобетонною основою. Досліджено два типи з'єднань: у першому стальна опорна пластина 3 привареною до неї вертикальною балкою кріпиться до залізобетонної основи двома анкерними болтами, які знаходяться на осі симетрії двотаврової балки, у другому - чотирма болтами. Навантаження прийнято двох типів: перше з'єднання зазнавало дії перерізувальної сили $\mathrm{i}$ згинального моменту, друге - перерізувальної сили, згинального моменту та осьової сили стиску. Реальну поведінку цих з’єднань описували за допомогою підходу, який враховує умови контакту та тертя між опорною плитою і залізобетонною основою. Підхід базується на однобічності залежності 
для контактної задачі з кулонівським тертям. Для підвищення точності числових розрахунків застосовано модифікований метод Лагранжа. Отримано діаграми в координатах момент-кутове переміщення та коефіцієнт гнучкості-відстань від вершини вертикальної балки до опорної плити. Визначено вплив степеня стійкості з'єднань на допустимі навантаження і деформації.

1. T. V. Galambos, "Influence of partial base fixity on frame stability," $A S C E J$ Struct. Div., 86 (ST-5), 85-108 (1960).

2. C. D. Nixon, The Design of Light Industrial Buldings, Ph.D. Thesis, Department of Civil Engineering University of Alberta, Alta, Edmonton (1979).

3. J. Lizotte et D. Beaulieu, Influence de la Fondation sur la Stabilité des Poteaux, Rapport GCT-81-05, Département de Génie Civil, Université Laval, Quebec (1981).

4. A. Picard et J. Dion, Étude Expérimentale des Assemblages Poteau Fondation dans les Charpentes d'Acier, Rapport GCT-81-04, Département de Génie Civil, Université Laval, Quebec (1981).

5. G. Samson and D. Beaulieu, Étude de la Stabilité d'un Poteau avec Attache Semi-Rigide a la Fondation, Rapport GCT-83-01, Département de Génie Civil, Université Laval, Quebec (1982).

6. B. Pérusse et D. Beaulieu, Etude Expérimentale de la Rigidité d'un Assemblage Poteau - Fondation de Type Standard, Rapport GCT-85-07, Département de Génie Civil, Université Laval, Quebec (1985).

7. Standard CSA S16.1-78. Limit States Design of Steel Structures, Canadian Standards Association, Toronto (1978).

8. Standard CSA S16-01. Limit States Design of Steel Structures, Canadian Standards Association, Toronto (2001).

9. Eurocode 3. Design of Steel Structures. 1.1. General Rules and Rules for Building (1992).

10. D. Beaulieu et A. Picard, "Contribution des assemblages avec plaque d'assise a la stabilité des poteaux," Constr. Métall., 2, 3-19 (1985).

11. R. E. Melchers, "Modeling of column-base behavior," in: R. Bjorhovde, J. Brozzetti, and A. Colson (Eds.), Connections in Steel Structures: Behavior, Strength, and Design, Elsevier Science Publ. Co., New York (1988), pp. 151157.

12. P. Penserini et A. Colson, "Caractérisation des liaisons structure métallique fondation: application en flambement des poteaux," Constr. Métall., 2, 43-52 (1992).

13. J. C. Ermopoulos and G. N. Stamatopoulos, "Mathematical modeling of column base plate," J. Constr. Steel Res., 36, No. 2, 79-100 (1996).

14. G. N. Stamatopoulos and J. C. Ermopoulos, "Interaction curves for column base plate connections," J. Constr. Steel Res., 44, No. 1-2, $69-89$ (1997). 
15. M. J. Konotoleon and C. C. Baniotopoulos, "Computational aspects on the frictional unilateral contact problem arising on steel base plate connections," Comp. Struct., 78, 303-309 (2000).

16. M. Dumas, D. Beaulieu, and A. Picard, "Characterization equations for steel column base connections," Canadian J. Civil Eng., 33, No. 4, 409-420 (2006).

17. M. Hamizi et D. Beaulieu, Études Expérimentale et Numérique des Pontages Métalliques, Rapport GCT-87-05, Département de Génie Civil, Université Laval, Quebec (1987).

18. L. Champaney, "Contact unilatéral entre solides élastiques," Notes de cours 'Eléments Finis' du DESS Dynamique des Structures Modernes dans leur Environnement.

19. J. C. Simo and T. A. Laursen, "An augmented Lagrangien treatment of contact problems involving friction," Comp. Struct., 42, No. 1, 97-116 (1992).

20. P. Brun et A. Picard, Étude d'un Assemblage Imparfaitement Rigide et des Effets de son Utilisation dans un Multiétagé, Rapport GCT-76-03, Département de Génie Civil, Université Laval, Quebec (1976). 